\title{
Economic Information in the Life and Death of the Soviet Command System*
}

\author{
Mark Harrison** \\ Department of Economics \\ University of Warwick \\ and \\ Centre for Russian \& East European Studies \\ University of Birmingham
}

\begin{abstract}
Information adds value to transactions in three ways: it supports reputations, permits customisation, and provides yardsticks. In the Soviet economy such information was frequently not produced; if produced, it was often concealed; whether concealed or not, it was often of poor quality; regardless of quality, it often suffered from low credibility outside the ruling circle. In short, the Soviet command system forced economic growth on the basis of a relatively low-value information stock. This may help explain aspects of Soviet postwar economic growth and slowdown, the collapse of the command system, and the persistence of low output after the collapse.
\end{abstract}

* This paper appeared as a chapter in In Reinterpreting the End of the Cold War: Issues, Interpretations, Periodizations, pp. 93-115. Edited by Silvio Pons and Federico Romero. London: Frank Cass, 2005. I thank the following for comments: Stephen Broadberry, Yoram Gorlizki, Paul Gregory, Peter Law, Valery Lazerev, and the participants in two meetings, the conference on "The End of Soviet Communism in Europe" at the Gramsci Institute Foundation, Rome, 10 and 11 May 2002, and the Economics Summer Research Euro-Workshop at the University of Warwick, 8 to 19 J uly 2002. I also thank Oleg Khlevniuk and Martin Lowry for helpful advice and further references.

** Mail: Department of Economics, University of Warwick, Coventry CV4 7AL, UK. Email: mark.harrison@warwick.ac.uk. 


\title{
Economic Information in the Life and Death of the Soviet Command System
}

\begin{abstract}
Without the most careful examination of all the statistical data that which we possess in far larger measure than at any other time and in any other country, without organising these data, without analysing them and generalising from them, no scholarly economic work is possible. It is a source of regret that the statistical data are still classified secret in the central statistical administration in comrade Starovskii's safes. ${ }^{1}$
\end{abstract}

What is the problem we wish to solve when we try to construct a rational economic order? [...] It is [...] a problem of the utilisation of knowledge not given to anyone in its totality. ${ }^{2}$

This paper is about the value of information in a command system. Paul David and Dominique Foray distinguish information from knowledge as follows: knowledge is the cognitive capability that empowers its owners to act, intellectually or practically, whereas information is merely the "structured and formatted data that remain passive and inert" until those empowered by knowledge use it. ${ }^{3}$ On board an aircraft, the instruments and charts provide information whereas the pilot has the knowledge of how to fly the plane using the information. Thus information is much less than knowledge. It is only a small part of the stock of intangible capital that is used to fly the plane or manage society. But information is still very important. In the classic formulation of Kenneth Arrow the value of information is that it reduces uncertainty. ${ }^{4}$ Flying in cloud or darkness, for example, the most knowledgeable pilot cannot pinpoint the plane's position and attitude relative to the ground without checking the dials on the instrument panel.

Three factors appear to make it timely to investigate the economics of information in command systems. One is that any study of information in command systems cannot be separated from the problem of official secrecy: why are there official secrets, and why does the coverage of official secrecy vary through time and across countries?

${ }^{1}$ A.I. Mikoian to the twentieth congress of the communist party of the Soviet Union, Moscow, 16 February 1956. Vladimir Nikonovich Starovskii was chief of TsSU (the central statistical administration of USSR Gosplan, later of the USSR council of ministers) continuously from 21 October 1940 to 6 August 1975.

2 Hayek (1945), 519- 20.

${ }^{3}$ David and Foray (2001).

4 Arrow (1984), 106- 14.

First draft 26 March 2002. This version 8 August 2002 
While there is a rich literature on the economics of concealment, including commercial secrecy, the issue of official secrecy does not appear to have been addressed; therefore, a gap in our understanding exists and should be remedied. Another is that the historical literature on Soviet official secrecy is written almost exclusively in moral and psychological terms of the rulers' paranoia, their excessive or pathological secretiveness, and so on, which diverts us from the necessary attempt to understand secrecy as a rational- choice process. Finally, a number of recent studies from the former Soviet archives are providing us with a growing mass of "information about information" which could help us to solve these problems.

From the point of view of the economics of information, however, this mass is almost entirely unstructured, so there still is a big empirical task in front of us. It is not just that we do not have measures of information, but also that we do not know how it should be measured. There is an aggregate stock of information in the economy that depreciates continually as information becomes outdated or irrelevant. New information is continually added; some of it updates or replaces old information, and some of it is new. Because information is dated and technology is changing, information of different dates is heterogeneous. Information can be digital or analogue. Digital information can be measured in internet pages, disk files, bytes and bits. Analogue information that is written and bound can be measured in volumes, pages, and characters, but analogue information also exists in film, tape, newsprint, and manuscript. This technical heterogeneity makes the stock of information and its growth hard to measure without ambiguity. Further, the uses of information are many; usually we cannot even distinguish between information that serves the economy's productive needs and that which serves our human curiosity and is therefore a consumption good. The value of information depends on our knowledge, and new knowledge can have unexpected effects; it can make some kinds of information completely obsolete, and make others suddenly valuable, for example we are continually finding new ways of using historical information.

But for the most part we are not very good at measuring information. What we tend to measure is not information itself but the spread of information technology, for example computer units, telephone lines, pounds of newsprint, and so on. I will try to focus on the concept of stocks of economically valuable information of various kinds, but the reader should not expect quick results.

The paper is organised as follows. Part 1 argues that the growing role that information plays in modern market economies is not just a consequence of its falling cost. The growing role of information also results from rising incomes. The evidence shows that as economic development proceeds and incomes rise information is demanded in much larger quantities and may even display increasing returns. Part 2 contrasts the uses of information in command and market systems. I will focus particularly on intermediate uses of information, rather than information as a consumption good. I will start from the assumption that information is exchanged so as to permit transactions that create a surplus for someone, and the distribution of the surplus is likely to be 
very important, but I will not analyse the creation of the surplus itself. Part 3 considers some specific uses of information: information adds more value to transactions that take place increasingly as incomes rise because it supports reputations, permits customisation, and provides yardsticks. In the Soviet economy such information was frequently not produced; if produced, it was often concealed in "comrade Starovskii's safes" or elsewhere. Often it was of poor quality; regardless of quality, it often suffered from low credibility outside the ruling circle. In short, the Soviet command system forced economic growth on the basis of a relatively low-value information stock. Part 4 considers the implications for Soviet postwar economic growth and slowdown, the collapse of the command system, and the persistence of a low level of output after the collapse. Part 5 concludes.

\section{Falling Costs, Rising Demands}

We are sometimes told that we are living in a "new economy". The basis of the new economy is said to be the rapidly falling costs and diffusion of new technologies for information storage, handling, and transmission from the desktop computer and mobile phone to the internet. Other aspects of the new economy, whether or not it has truly accelerated growth, are said to include declining old industries, the growth of new industries producing machinery and specifically IT equipment, the rise of the information and financial services sectors, and globalisation. ${ }^{5}$

I single out the rise of services because the products of the services sector are relatively information-intensive. Information is a final product of the news, entertainment, and publishing media. Agencies engaged in business consulting, market research, credit evaluation, and economic forecasting consume it and supply it to other business users. Information is essential to the provision of personal services that range from education, health care, and the long- term care of sick, disabled, and old people, to housing, labour market and financial services. Community services such as defence, policing, the administration of justice, and public accounting rely in obvious ways on the flow of information.

The rise of services has recently accelerated but has long historical roots. This is one piece of evidence that supports the idea that the new economy may not be so new and has probably been emerging for centuries. Table 1 shows that the employment share of services in three of the most developed industrial economies has been growing since 1870. Its growth has been continuous in the United States, whereas in Britain and Germany the industrial efforts of World War II interrupted the trend. But if we take 1930 as an intermediate benchmark the table also shows that the gain in the employment share of the services sector over the last sixty years in each country was at least twice that of the first sixty years, and this supports the idea of an underlying

${ }^{5}$ For a survey of uses, leading and misleading, of the idea of a "new economy" see Madrick (2001). 
acceleration of the restructuring of production towards services since World War II.

No single factor has been associated with the rise of the "new economy" more than diffusion of the personal computer. Within twenty years the United States has gone from negligible availability to a position where there is one PC for every employable adult. Other leading economies are not far behind. ${ }^{6}$

Table 1. Employment in Distribution, Finance, and Services, 1870 to 1990: the USA, UK, and Germany, Selected Years (per cent of total employment)

\begin{tabular}{lccc}
\hline \hline & $\begin{array}{c}\text { United } \\
\text { States }\end{array}$ & $\begin{array}{l}\text { United } \\
\text { Kingdom }\end{array}$ & Germany \\
\hline 1870 & 18.3 & 27.0 & 16.0 \\
1910 & 26.2 & 32.3 & 19.5 \\
1930 & 33.1 & 35.2 & 22.3 \\
Increase, 1870 to & +14. & +8.2 & +6.3 \\
1930 & 8 & & \\
1950 & 40.0 & 31.7 & 21.1 \\
1990 & 62.2 & 57.0 & 36.1 \\
Increase, 1930 to & +29. & +21. & +13. \\
1990 & 1 & 8 & 8 \\
\hline
\end{tabular}

Source: Broadberry (1997), 64.

Current rates of decline in information and communication costs are dramatic by any standard. For example, in the three decades from 1930 to 1960 the cost of a three- minute transatlantic phone call fell by 5.4 per cent a year, but this rate increased to 8.4 per cent annually in the next three decades from 1960 to 1990. In the three decades from 1960 to 1990 the US Department of Commerce computer price deflator fell at 14.9 per cent a year, and at 27.6 per cent a year in the 1980s alone. ${ }^{7}$ More recent estimates show further acceleration, with performance- adjusted personal computer prices falling at 30 to 40 per cent annually in the 1990s. ${ }^{8}$ It is a striking irony that the years of accelerating global decline in information costs are also roughly the period over which the Soviet economy decayed and then collapse.

There may be historical parallels in past diffusion curves of radio and television, telegraph and postal services and mail order, and newsprint and books. The cost of the printed word followed a similar curve in the years after the introduction of the printing press. Before

6 World Bank (2001), World Development Indicators. In the United States in 1999 there were 511 PCs in use per thousand of the population, followed by Australia (469) and Switzerland (462).

${ }^{7}$ Calculated from figures cited by the International Monetary Fund (1997), 46.

8 Landefield and Grimm (2000), 19. 
printing, a single book might represent months or years of a scholar's income. Only the church or the crown could maintain a library. ${ }^{9}$ With the introduction of printing to Italy in 1465 the price of books is said to have fallen by 80 per cent in just three years. This decline was repeated in the years that followed because falling prices then widened the market and enabled a rapid increase in printing runs; by the early sixteenth century editions of 3000 copies were not uncommon. After this time, however, book prices stabilised for a lengthy period. ${ }^{10}$

The decline in information costs during such episodes may be astonishing and spectacular, but it is only part of the story. Conventional analysis of the information age focuses on falling costs because our attention is naturally drawn to the historical episodes of dramatic cost decline, one of which we are living through now. Moreover it cannot be denied that falling costs are very, very important. However, the relationship between information and economic growth has roots that are not only longer in historical terms than are often imagined, but also deeper than a narrow focus on falling costs would imply. We are not just observing a slide down a fixed demand curve that widens the market as costs fall. The uses of information have been driven by rising incomes as well as by falling information costs. Income growth is slow and gradual. However, there is unambiguous evidence that information becomes more useful as incomes rise and would be demanded in greater quantities even if costs did not change.

Cross- country comparisons at a point in time show clearly how the demand for information handling capacity rises with income when costs are given. This relationship is well established and robust, and it can be observed in quite widely separated historical periods. As far back as the 1930s incomes were correlated with the availability of information and communications facilities across countries just as strongly as with ingots of steel or kilowatts of electric power. ${ }^{11}$ Lenin and Stalin thought they were living in the age of steel and electricity, but they were wrong: a new era was already overtaking them. Similar evidence from the present day confirms that the age of information is not driven by falling costs alone. ${ }^{12}$ For given technologies available at

9 Bell (1936), 331; Cipolla (1956), 57- 63.

${ }^{10}$ I thank Martin Lowry for this information, based on his own research and reference to Giovanni Andrea Bussi, Prefazioni alle edizioni di Sweynheym e Pannartz prototipografi Romani, a cura di Massimo Miglio (Edizioni il Polifilo, 1978), and Anna Esposito, Anna Modigliani, and Paola Scarcia Piacentini, "Il costo del libro", in Scrittura, biblioteche e stampa a Roma nel Quattrocento, Atti del Seminario 6- 8 Maggio 1982, a c. di M. Miglio (3 vols, Citta del Vaticano 1983), vol. II, 323- 553.

${ }^{11}$ Harrison (1994), 249- 51.

${ }^{12}$ For data on the present- day cross- country distribution of personal computers, televisions, telephone mainlines, and mobile phones, strongly correlated with incomes, see World Bank (2001), World Development Indicators. 
given costs, relatively wealthy countries have found it advantageous to invest much more heavily in information capacity than poor countries. This may be because information is a luxury good so that rich people are willing to spend proportionately more to obtain it, or because information has higher returns in the activities in which rich countries specialise.

It seems likely that information displays diminishing returns when other factors are controlled. However, network externalities clearly ensure increasing returns over a certain range to items of information technology equipment such as video and fax machines, telephones, and PCs. ${ }^{13}$ Further, while returns to information may strictly diminish at the margin for a given activity, it is possible and even likely that average returns tend to be higher in those activities such as services that grow most rapidly as incomes rise. Hence, the value of information may rise with incomes and the level of economic development.

\section{Hierarchy and Secrecy}

In order to understand the scope and purposes of information stocks in the Soviet economy, it is necessary to note the differences between command and market systems. In a market that is competitive the important relationships are horizontal: buyers and sellers meet and compete on approximately equal terms. Market information is available to all or, if costly, is itself a commodity that can be supplied and demanded. A hierarchy is a vertical network of principals and agents. ${ }^{14}$ In the Soviet command economy most enterprises were state owned and most producers were agents of a government principal, usually a minister, the ministry being the legal fundholder. Horizontal relationships of supply and demand were organised by order from above through vertical hierarchies rather than directly between buyers and sellers on a voluntary basis. Vertical subordination was based on the principle that orders flowed downwards while information flowed upwards and did not leak downwards or sideways.

An essential feature of the Soviet command system is that its hierarchies were complex: there were many parallel hierarchies with functions that were necessarily specialised and often overlapping, that converged at the top in a unified leading body such as the council of minsters and the politburo. And of course there were minor parallel hierarchies within every major one. None of these hierarchies could fulfill its functions in isolation, without horizontal exchanges that required contact with others. For example the defence ministry had to purchase equipment and fuel from industry and food from agriculture; the ministry for engineering had to buy metals from the steel industry and power from the electricity generating industry. These exchanges were first of all authorised in very broad outline in high- level plans and decrees, and then the ministries themselves had to negotiate detailed

\footnotetext{
${ }^{13}$ On network externalities see Katz and Shapiro (1985).

${ }^{14}$ On vertical and horizontal networks see Wintrobe (1998), 212- 13.
} 
contracts for specific commodities that implemented the plan. ${ }^{15}$ Implementing these contracts rested on budget authorisation by the ministry of finance and credit authorisation by the state bank. Meanwhile the criminal and security police, planners, and party activists selectively monitored activities and transactions and tracked their consequences.

Within these complex hierarchies principals were faced with two kinds of opportunistic action on the part of agents that might restrict or dissipate the principal's rents. One was the agent's ability to influence the principal arising from the agent's control of the upward flow of information. The other was the agent's ability to collude with contacts in parallel hierarchies in unauthorised horizontal transactions that might profit the agent to the loss of the principal.

The practice of secrecy was a mechanism that effectively supported vertical structures at the expense of horizontal ones. Secrecy itself had two aspects. One aspect was the strict rules limiting the downward transmission of information. For example, between 1930 and 1941 the government and its main economic committee made more than 32000 decrees but less than 4000 of these were openly published, and more than 5000 received the top security classification which meant that they remained known only to a few top officials. ${ }^{16}$ Secrecy extended both to decisions and to the decision making process itself. The principles of "conspirativeness" (konspiratsiia), approved by the party politburo in the late 1920s, were aimed at limiting knowledge of the business of the politburo and central committee to the narrowest possible set of participants and, in the process of transmitting decisions downwards, to deny information to lower levels about the sources and context of higher- level decisions. Moreover, on 5 March 1931 the politburo resolved "categorically to forbid people with the right of acquaintance with the decisions of the c[entral] c[ommittee], when passing instructions onward in the apparatus, to refer to the fact that these instructions are decisions of the c[entral] c[ommittee]". ${ }^{17}$

Such secrecy cannot only have been designed to prevent breaches of national security or to prevent society from holding the government and ruling party to public account. It was also designed to influence the behaviour of those within the state, but below the apex of power. If officials and activists at the middle level of the nomenklatura knew nothing of the decisions being made above them and of the superior bodies making them, they could be prevented from learning how to shape and direct information and lobby superiors so as to influence decisions in their own private interests.

Another aspect of secrecy was the construction of elaborate firewalls within the state to inhibit horizontal transfers of information among

${ }^{15}$ Our knowledge of inter-ministerial contracting in the Soviet economy was virtually non- existent before the archives. See Harrison and Simonov (2000), Belova and Gregory (2001), and Belova (2001).

${ }^{16}$ Davies (2001), 63.

${ }^{17}$ Khlevniuk et al. (1995), 85; see also 73- 82. 
the parallel hierarchies. Again, these firewalls could hardly have been justified on grounds of national security or even by a desire to protect the authority of the state as a whole over society. Even within the government information was shared on the basis of need, not right to know, and the need to know was defined within limits that appear sometimes extraordinarily narrow. For example, in August 1948 the deputy chief of the interior ministry (MVD) Ivan Serov wrote to his boss Lavrentii Beriia that in the process of drafting the 1949 budget the ministry of finance was demanding to be informed of numbers in prisons, labour camps, and prisoner of war camps "and their physical condition", numbers of internal security troops, and figures for gold output and the gold content of ores; these figures were required to budget for the required outlays by the MVD on wages and subsistence. Serov warned: "Provision of these figures will lead to familiarisation with especially important information on the part of a wide circle of staff of the USSR Ministry of Finance, the State Bank and the Industrial Bank". An accompanying memorandum advised Beriia that in past years such figures were loaned temporarily to the finance ministry to be processed by no more than two or three highly trusted workers, then returned; it noted that the ministries of the armed forces and state security provided the finance ministry only with financial summaries, not head counts; and it proposed that from now on the MVD do the same. 18

Such firewalls were often buttressed by a low- trust environment that helped to align agents' incentives with those of their principals. For example, the archives show that in the 1930s industrial producers of military products frequently refused to release information about the production cost of weapons to the defence ministry, which was the purchasing department. They justified this on the grounds that equipment costs were a military secret that the defence ministry was not entitled to know, but of course this was a crude excuse: they did so simply because it promoted their horizontal bargaining power. 19

A number of interlocking mechanisms thus inhibited horizontal transactions. Unauthorised contracts among lower level agents to engage in horizontal trades were prohibited and were not legally enforceable. In addition vertical networks of patronage and protection encouraged agents to invest in relationships of trust and dependence with superiors rather than with their opposite numbers in parallel hierarchies.

By protecting their information from horizontal spillage principals successfully strengthened their vertical hierarchies. However, the reinforcement of hierarchy was achieved at a cost, and this cost was

${ }^{18}$ Gosudarstvennyi Arkhiv Rossiiskoi Federatsii, Moscow, fond 5446, op. 50a, delo 4043, folios 1-2. On Serov's memorandum is noted by hand: "Comrades Popov and Serov: consider and resolve. L. Beriia". I thank Oleg Khlevniuk for this reference. For a similar example from the 1930s see Harrison (2001a), 96.

${ }^{19}$ Harrison and Simonov (2000), 232- 5, and further Barber et al. (2000), 19- 23. 
paid in the diminished quantity and quality of information that flowed upwards from agent to principal. Quantities of information that flowed upward were limited by the common interest of both principal and agent. The upper reaches of the hierarchies had a very limited information handling capacity. This was only partly because of technological limits, although it should not be forgotten that until the end of the Soviet regime many officials had nothing more sophisticated on their desks than an abacus. In addition, the politburo and ministers positively preferred to rely on small expert staffs; evidently this made it easier to share motivation and sustain unified leadership. ${ }^{20}$ There were many kinds of information that the commanders of the system simply did not want to know; they did not want to be bothered with every petty setback or failure, preferring to place responsibility on those at lower levels to sort things out without the assistance of higher authority. But it also suited those at lower levels to preserve their own freedom of action by keeping their superiors underinformed. ${ }^{21}$

Vertical relations also worked to spoil the quality of information. Because profitable opportunities for horizontal exchanges that undermined the plan were everywhere, principals needed good information about what their agents were doing. For the same reason, however, agents had strong incentives to conceal or lie about their activities. And for another reason too: even if the returns to concealed horizontal exchanges were sometimes low relative to the high risks and penalties involved, the most profitable alternative for the agent was not necessarily to obey orders, because carrying out instructions also required effort, and doing nothing required just as much concealment as doing something that was actively illegal. Thus, although downward and horizontal transfers of information were successfully impeded, the flows of information vertically upward became sluggish and were frequently distorted. ${ }^{22}$

While principals appear to have discouraged inferiors from lobbying in general, under specific circumstances they encouraged it because it helped to overcome the reluctance of agents to volunteer information. In a context of competition for resources and favours, rival agents were all too willing to supply principals with information of two kinds: about the relative worth of competing spending projects that were available for the principal to select, and about the relative loyalty of competing agents. This strategy was followed, for example, to create a "market for inventions" in the defence industry. ${ }^{23}$ The information resulting could be plentiful, though recognisably biased. Its supply depended on

20 Gregory (2001), 14- 16.

${ }^{21}$ Belova and Gregory (2001).

${ }^{22}$ As a result the detailed information that reached the summit was sometimes not trusted as a basis for planning decisions and supraministerial agencies incurred costs in gathering data independently to duplicate and cross- check that supplied through the ministerial hierarchy. See Gregory (1990), 37- 8.

${ }^{23}$ Harrison (2001b), (2001c). 
enforcing rivalry among agents at lower levels through a policy of "divide and rule"; if they formed horizontal links and learned to collude, the flow of information was worsened in both quantity and quality. ${ }^{24}$

In summary, the role of information was quite different in the command system compared with a market setting. Specifically, principals had strong incentives to collect true information but these incentives were substantially weakened by the high costs of collecting and handling it. Agents often had only weak incentives to collect information or provide true information to principals, and strong incentives either to withhold or distort it. The equilibrium outcome was characterised by limited information stocks of poor quality.

\section{Market Information in a Command System}

The tradition of Austrian economics emphasises the role of markets as information systems in which prices enable reallocation by acting as signals. ${ }^{25}$ Indeed this provided the argument by which that tradition sought to establish the superiority of the capitalist economic system over socialism. The focus of this paper is a little different: it deals with various ways in which the exchange of non- price signals can add value to transactions. Without this information the transactions that take place would either be of lower value or would not take place at all. I distinguish three ways in which information adds value to transactions: it supports producers' and consumers' reputations, permits customisation of products, and provides yardsticks that are useful to all agents in comparative evaluation of products, producers, and investments. Reputation and customisation depend on the diffusion of specific information, that is information about individual consumers and producers. Yardsticks on the other hand are enabled by "general knowledge", that is knowledge about the economy in various aggregate dimensions.

\subsection{Brands, Advertising, and Reputation}

In markets for goods and services where there are many brands and many sellers, advertising informs consumers of the availability and price of new products and reduces their costs of searching. ${ }^{26}$ Where the quality of a product matters and consumers cannot easily tell good products from bad ones before purchase, producers can command a premium if they invest in a good reputation. ${ }^{27}$ However, for the same reasons that Soviet producers did not need to know their markets, they

24 Harrison (2001d).

25 Hayek (1945).

26 Stigler (1961).

27 According to Stigler (1961), 224, "Reputation commands a price [...] because it economizes on search". For elaboration see Shapiro (1983). 
had little reason to acquire reputation with the final users of their products. For related reasons producers did not advertise: Most Soviet consumers took what they could get without having to choose among brands or to seek out the lowest price. It was enough to be able to buy at all.

In a seller's market the information of most value to consumers was to know for certain that a given commodity would be available in given quantity at a given time and place. Knowledge of availability was more important than knowledge of quality or even price. Market research that predicted availability would have served consumers, but was of no interest to producers. Without it, such market intelligence was circulated on the twin basis of rumour and privilege, and was traded within the "economy of favours". 28

It would be wrong to conclude that business reputation did not exist at all in the command system. Reputations were attached to both products and agents. Particular branded products were widely known for high quality: for example Stolichnaia vodka, Red October chocolate confectionery, the Bolshoi ballet, and MiG aircraft. This reputation was based primarily on consumers' experience, but the payoff came from reporting this experience within the vertical hierarchy. The market reputation brought no return; it was the reputation in the hierarchy that won rewards for the producers. These rewards were extremely varied. Organisational team benefits took the form of priority access to financial and material resources for production and the establishment of privileged retail, housing, and welfare clubs for employees. Individual benefits ranged from cash premia and state decorations awarded to leading individuals to the chance to travel abroad and retain some foreign earnings.

What factors formed the business reputation of an agent? Again reputation could be formed on both horizontal and vertical lines; however, whereas the market reputation of a product reinforced its reputation in the hierarchy, the reputation of an agent was formed in a more complicated way.

Agents' reputation with superiors was formed by both productivity and loyalty, but the weighting of these two factors was variable and the size of the return was uncertain as well. For example, a study of Soviet regional policy has shown that Stalin used investment allocations to reward loyal agents in the regions in his struggle with the opposition in the late 1920s; during the 1930s, however, his regional agents were called to account for their wasteful use of these resources. ${ }^{29} \mathrm{~A}$ detailed study of the Soviet allocation system for motor vehicles in the 1930s also shows that the dictator held a stock of vehicles in reserve for use as rewards for loyal agents. ${ }^{30}$ In aviation research and development, in contrast, although Stalin had clear favourites and proposals required investments in lobbying to gain initial finance, a reputation for loyalty

${ }^{28}$ On Russia's "economy of favours" see Ledeneva (1998).

29 Harris (1999).

30 Lazarev and Gregory (2001). 
was no protection against deprivation of funding and sometimes also punishment in the event of productive failure. ${ }^{31}$ Thus it appears that under Stalin loyalty alone was not enough. Perhaps, however, the slowdown of elite circulation that followed the dictator's death permitted an increase in the importance of loyalty relative to that of productivity, with adverse consequences for the health of the command system.

In unauthorised horizontal contacts the ability to complete transactions depended on a business reputation for plain dealing and keeping one's word. Eugenia Belova has described the unauthorised "relational" contracting system that arose where contracts were costly to enforce or unenforceable by other means..$^{32}$ Relational contracts typically rested on a handshake and were enabled by experience of personal contact and friendship; only these could overcome the culture of low trust. 33

An agent could exploit a good horizontal reputation to support a vertical reputation. Vertical reputation rested on fulfilling the plan, but the plan was highly aggregated and did not foresee many specific details of the inter- ministerial transactions necessary to achieve it. The system of inter- ministerial contracting that underpinned the aggregate plan was also highly incomplete. In order to supplement the plan and eventually fulfill it agents were frequently compelled to make unauthorised horizontal contacts and deals. Thus a horizontal reputation for honesty among equals could support a vertical reputation for serving superiors. This created a problem for principals, however, who could not easily distinguish those unofficial deals that agents made so as to fulfill the plan from those that helped agents to cheat the state and line their own pockets. Perhaps an agent's horizontal reputation could be "too good": to be well thought of by everyone could too easily be a cover for embezzlement or worse.

Similarly, a vertical reputation that was "too good" could damage horizontal reputation. Eugenia Belova finds evidence that a bad vertical reputation could signal a readiness to do unofficial business on horizontal lines. While relational contracting should have become more efficient as personal networks increased in scope, she argues, it was not in the interest of principals to allow such horizontal networks to expand without limit. As a result horizontal reputation could only accumulate privately or within small groups. ${ }^{34}$

In market economies a further dimension of reputation is information about specific consumers. Consumer reputation is important primarily for consumer credit. Banks, loan societies, and credit card agencies prefer to lend only to individuals with desirable characteristics such as fixed places of residence, collateral assets, and good repayment reconds. In the Soviet command system these things

\footnotetext{
31 Harrison (2001b), (2001c).

32 Belova (2001).

33 Gregory (1990), 91- 2.

34 Belova (2001).
} 
were mostly unimportant. Without a freehold property market no one wanted to acquire a housing mortgage. Consumer debt did not arise either; in a shortage economy most consumers had plenty of liquidity in the form of either cash assets or waiting time.

Individuals' status as producers and their political reputation with superiors carried more weight than any financial credit rating. Another way of putting this would be to say that the currency in which people were rated for credit worthiness and were able to accumulate debts was measured in loyalty and favours. This "currency" was traded privately subject to special rules of reciprocity and was not convertible into rubles. The information on the basis of which this trade took place was correspondingly private and not available for dissemination to others.

\subsection{Customisation}

In the early twentieth century, mass production brought the cost of consumer durables down to the point where they could become items of mass consumption. The result was a high degree of market penetration by relatively uniform, standardised products. Henry Ford said of his family automobiles: "You can have any color you want, as long as it's black". ${ }^{35}$ The same went for radio, telephone, and television sets. At lower incomes price tended naturally to be more important than variety, although when controlling for income consumers in different countries still differed somewhat in their willingness to trade off variety or quality. ${ }^{36}$

In market economies customised products are able to command a premium over standardised, mass- produced commodities. But customisation implies a great increase in the exchange of information required to complete a transaction. In the era of mass production the consumer bought a uniform product in the combination of attributes determined by the producer. Today flexible production means that, by recombining their attributes in different ways, suppliers can customise goods and services to the needs of individual purchasers without loss of economies of scale.

Mass customisation, sometimes also called "mass personalisation", is enabled by the increased information that producers can obtain about consumers. In wealthy countries today big companies carry out market research, or employ specialised research agencies, to develop huge databases that store household- or individual- level data about characteristics and preferences. For more complex products consumers themselves provide the information about their preferences "just in time". For example a buyer ordering a computer over the internet specifies the processor make and speed, chip and disk memory, additional drives, modem capacity, display type, sound card, multi-

35 This is what Henry Ford is said to have said in 1929, or in 1933, or at some other date, of the Model A, the Model T, or some other Ford vehicle, according to hundreds of internet references registered by www.google.com.

36 Broadberry (1997), 77- 89. 
media facilities, and so on; this information is then transmitted directly to the assembly line programme.

In the Soviet economy information about product prices and characteristics was not readily available in such detail. Indeed it may not even have been produced. For example the Soviet statistical archives appear to hold price and quantity information about every product ever produced in a state- owned enterprise, but even for the most complex and costly machinery this information does not appear to extend to more than two or three product characteristics. ${ }^{37}$ By comparison the marketing and mail order catalogues available to most American consumers from the early twentieth century onward convey many times this quantity of information per product. The information provided was not only enough to sell the products but also to support subsequent studies of hedonic pricing of durable goods that have routinely used such catalogues for their primary data. ${ }^{38}$ In contrast the information held in the Soviet archives was collected specifically to support planning targets based on quality- adjusted pricing but did not in fact do so; on the contrary, it permitted concealed inflation. 39

Similarly, Soviet producers did not need or carry out market research into consumer characteristics. Mass production displaced the artisan system of producer- driven customisation in the 1930s and 1940s. 40 Thereafter, the Soviet economy remained wedded to mass production. Standardised clothing, household durables, and civilian and military machinery supplied an undifferentiated market. The state procured and distributed output, breaking the link between supplier and final purchaser. The seller's market left producers with no incentive to become informed about the market, and no means of doing so because the state insulated them from market responses. The state monopoly of foreign trade cut producers off from the export market even more thoroughly than from the home market, and exporters were given no special incentives to tailor production to the requirements of foreign buyers. ${ }^{41}$ Only the defence ministry had the power to enforce customisation upon producers through its institutionalised presence in defence industry and power of veto in the procurement process. ${ }^{42}$

In practice there were two ways in which Soviet products and services could command a real premium in return for variation of attributes. The first was provided by the command economy, which allocated an implicit premium to new and regraded products by pricing them favourably in relation to existing products. This was not a

${ }^{37}$ Rossiiskii Gosudarstvennyi Arkhiv Ekonomiki, fond 1562, contains the files of the USSR central statistical administration (TsSU SSSR) that have been declassified up to 1963.

38 For example Gordon (1990), especially 417- 89.

39 Harrison (1998a), (2000a).

40 On mass production in defence industry see Harrison (2000b).

${ }^{41}$ Holzman (1974).

42 Harrison and Simonov (2000). 
deliberate policy but arose as follows: plan prices were based on product costs so as not to reward cost cutting at the expense of product quality, but the authorities could not process complex information about product quality so as to distinguish cost increases associated with the customisation of products to the market from those designed to attract a rent at the expense of society. Thus "simulated" innovation paid more than true innovation, and producers obtained rewards for product variations that increased costs rather than quality. ${ }^{43}$ The outcome was customisation of products to the plan, not to the final consumer.

The other way in which products and services could command a return on varied attributes was through illegal trade and side payments. In these respects the Soviet economy returned the concept of customisation to an artisan framework of semi- legal or illegal selfemployment or unregulated small- scale trade. For example, in the market for commodities western imports were one source of customised products that could command a premium. To the consumer the main positive attribute of western clothing or household equipment was simply that these were different from the standardised Soviet article. The premium payable was reduced, however, because access to imported commodities depended on privilege more than purchasing power. Thus the possibility of buying denim jeans from tourists was restricted mainly to those with a Moscow or Leningrad residence permit. Similarly, personal services from housing maintenance to medical care were often customised to the individual consumer through bribery and side payments, but in the "economy of favours" being able to trade a privilege could count more than purchasing power.

\section{3. "General Knowledge” and Yardsticks}

In market economies specific transactions are enabled by combining different kinds of information. Information that is specific to the transaction ("What am I buying? How much does it cost? How much do I need it?") is essential but often specific information alone is not enough. To complete the transaction general knowledge is required as well. Are similar products available elsewhere for less? What other products are available? For durable goods time will also enter the equation: will the price fall? Will something substantially better come along in a year or two? Will needs change? Typically problems that involve time, such as investment choices or providing for retirement, are especially demanding of general knowledge. Producers must forecast aggregate trends as well as those specific to their own market. Individuals must predict their lifetime capacity to save and the lifetime return to saving in the context of macroeconomic and demographic trends.

In all these cases we use general knowledge of trends in the economy as a whole to provide yardsticks against which we can judge

43 Berliner (1976), 375- 80; Harrison (1998a). 
individual firms and products. ${ }^{44}$ For example we may judge product prices against the retail price index, share performance against the Wall Street index, or fixed-interest financial products against the Bank of England's discount rate.

Yardsticks also play an essential role in informing policy choices and choices in political markets. We rank police forces by crime and detection rates and use this information to judge chief police officers. We judge health administrators by waiting lists and operation success rates in hospital league tables, teachers by pupils' exam performance in league tables of schools, and politicians by the economy's place in league tables of unemployment, inflation, real growth, and environmental quality. An external yardstick for the Soviet economy in this sense was sometimes the economic performance of the west, as when Stalin set the goal to "make good the distance we are lagging behind the advanced capitalist countries" or "to outstrip the principal capitalist countries economically". ${ }^{5}$ Soviet leaders also benchmarked their own technologies against specific western products and processes; Stalin himself sometimes withheld support from new ideas until they had been tested by Western experience. 46

Such use of general knowledge can result in intense pressure on the independence and objectivity of those who produce it: business consortia, academic organisations, and government bureaucracies. ${ }^{47}$ The pressure is facilitated in so far as each has a natural monopoly in the supply of information about themselves that cannot easily be checked. Therefore the structure of the market for statistics has an important influence on their quality. To assure this quality usually requires a combination of transparent sources and methods, regulation through audit, and constitutional guarantees of independence from operational concerns.

44 Shleifer (1985) proposed "yardstick competition" as a means of regulating franchised monopolies. Franchised monopolies typically have little incentive to reduce costs. However, if the price that the regulated firm receives is made to depend on the costs of identical firms, then in equilibrium each firm will choose a socially efficient level of cost reduction. Yardstick competition is recognisable in a Soviet context as the idea behind "socialist emulation", with the difference that Soviet competition were aimed not at cutting costs but at increasing gross output.

45 “The Tasks of Business Executives” (4 February 1931) and "Report on the Work of the Central Committee" to the eighteenth party congress (10 March 1939), both reproduced in Stalin (1940), quoting from pages 367 and 634 respectively. For a survey and history of Soviet expert attempts to benchmark the Soviet economy against western yardsticks see Kudrov (1997).

46 Holloway (1994), 147.

47 In the terms of Arrow (1984), 142, yardstick information is indivisible and inappropriable. It is a public good by definition and this explains why it is not typically supplied on a private basis. 
In the Soviet economy much information of a potentially "yardstick" character was not required because restrictions on agents' freedom of action would have prevented them from benefiting from it; even if required, such yardsticks were frequently not supplied, and remained locked in "comrade Starovskii's safes" or elsewhere. Such yardsticks, even if supplied, were often of unreliable quality. The quality of statistical information was usually unchecked: the government statistical service was allowed to exercise a monopoly over statistical work, and was itself a loyal instrument of the political class. ${ }^{48}$ Whether or not they were reliable, the general public often found government statistics not to be credible, as in the saying “Izvestiia ('The News') isn't the truth (ne pravda) and Pravda ('The Truth') isn't news (ne izvestiia)". Interestingly, government statistics found credibility only within the closed world of the ruling circle; for example, the leaders relied on the official growth rates when no one else did. This may be seen as an important and interesting paradox, sometimes described in terms of an out- of- touch elite believing its own propaganda that the rest of the world could see as transparent lies.

Let us examine specifically two aspects of this, the changing propensity to conceal useful information, and the credibility gap between rulers and society. To begin with, consider the availability of information that would have usefully contributed to general knowledge, for example crime rates, rates of alcoholism, disease and death rates, harvest levels, the money supply, and real growth and inflation rates were all on the secret list at one time or another. Evidently, such concealment inhibited the establishment of yardsticks by which the performance of government and the economy could be evaluated; in this way it diminished accountability. It also resulted in two kinds of waste. First, in the absence of yardsticks some people made costly mistakes; for example, many Russians counted on the command system to provide them with pensions in retirement and saved less for their old age than they might have otherwise, or saved in the wrong form, in rubles that are now worthless; as a result they are now unable to retire, or live in poverty. Second, those for whom yardstick information mattered had to use resources unnecessarily in order to duplicate it, for example disseminating information about society by costly samizdat. 49

Soviet yardsticks were not all concealed consistently. The propensity for suppression followed a protracted cycle from relative openness in the 1920s to the almost total statistical blackout of 1937 to 1956 , followed by a return to greater openness in the 1960s and 1970s, always with qualifications and partial retreats until the flood of revelations associated with glasnost'.

48 Wheatcroft and Davies (1994). On planners and statisticians as "honest brokers" within the Stalinist dictatorship see Belova and Gregory (2001).

${ }^{49}$ Arrow (1984), 143, specifies a third cost of secrecy when secrets can be traded privately, the destruction of markets for sharing risks. In the Soviet case such markets were precluded anyway. 
Why were such facts revealed in some periods but not in others? There appear to have been three reasons. First, without providing general information from time to time the regime could not credibly claim responsibility for economic advances and thus hope to win the population's loyalty. ${ }^{50}$ Thus, a regime choice that shifted the underpinnings of power away from repression towards loyalty could tip the balance in favour of a policy of revelation that would allow the establishment of performance yardsticks. Second, for the same reason at times of regime change it often suited a new leader to reveal the failings of the old ones in order to blame them and avoid carrying responsibility for their failures. Third, at times when the regime chose to seek wider involvement of the intelligentsia in solving economic and cultural problems greater openness became necessary in order to foster critical discussion and evaluation of existing policies. All three motives were evident in the spring of 1956 in Mikoian's public plea to "comrade Starovskii" to open his safes.

In one respect a command system that practised a degree of statistical openness might be regarded as providing better information than a market economy. The information that is needed to make optimal production and consumption decisions includes information about the future prices of commodities but in market economies such futures markets mostly do not exist. The command system did not provide information about future prices, but it did at least provide guidelines about future quantities in the shape of detailed plans for future national economic development. 51 In practice, however, this information was of limited value since plans were not implemented in any detail. In the words of Eugene Zaleski the Stalinist plan was a "vision of growth [...] The Soviet experiment shows that, in order to exert a real influence, the vision does not have to be very accurate". 52

In periods of greater openness a problem was that much of the information revealed was itself of very low quality and unreliable as a basis for making decisions. The very fact that Soviet statistics were designed to be used as success indicators led to their distortion in ways that have been well known for many years. ${ }^{53}$ Some observers have attributed very large consequences to low- quality macroeconomic yardsticks in Soviet history. For example, Grigorii Khanin has argued

50 For the underlying theoretical argument see Wintrobe (1990), 857, 864.

51 "Even as a graduate student”, writes Arrow (1984), 160, "I was somewhat surprised at the emphasis on static allocative efficiency by market socialists, when the nonexistence of markets for future goods under capitalism seemed to me a much more obvious target".

52 Zaleski (1971), 297.

53 Nove (1958); Treml and Hardt (1972); Davies and Wheatcroft (1994). "Goodhart's law" (see Goodhart, 1984, 96) states: "any observed statistical regularity will tend to collapse once pressure is placed upon it for control purposes", in the Soviet case, for example, the relationship between observed and true real output. 
that exaggerated claims to success made the Soviet regime complacent about economic stability, encouraged an official belief in the ability of society to shoulder fresh burdens, and inhibited necessary adaptations to changing economic requirements in the 1970s and 1980s. 54 From the standpoint of official data, the worsening of Soviet economic conditions remained largely invisible; serious long-term problems were admitted, but no crisis. Meanwhile, unofficial experience told all too clearly of the sharply worsening quality and availability of goods and services. Soviet leaders' reliance on official yardsticks, which blanked out the true picture and shielded them from the necessity to act, explains the uncomprehending complacency. The upsurge of economic discontent, followed by a turn to terminal disintegration, simply took them by surprise.

Khanin has shown that at least some who participated in the making of policy understood the defective character of their information and tried to improve it. ${ }^{55}$ They were opposed, however, by strongly entrenched interests that were vested in distortion and concealment. With hindsight we see that the "errors" that resulted were a permanent feature of the Soviet command system: distorted statistics suited the policy biases that led to famine and demographic disaster in the 1930s, and to less dramatic but still costly losses in the postwar period.

Given this, why do we find that Soviet statistics commanded more credibility in the Kremlin than in the street? An answer may be found in the literature on signalling: diversity of preferences between sender and receiver may limit the information that can be credibly conveyed. 56 Consider the possible range of preferences for high effort and high accumulation on one hand, versus low effort and consumption on the other. Stalin's brutal treament of statisticians in the 1930s may be interpreted as a process of aligning their preferences with his, which were for high effort and accumulation. Once accomplished, this ensured that the statistics they produced were believed in the Kremlin. But the dictator's preferences diverged from those of society. This can explain why officially "honest brokers" were believed officially while seen as dishonest in unofficial circles. It also explains the sudden brutality with which Stalin reacted when for any reason he began to doubt their loyalty, which was essential to his mechanisms of power. ${ }^{57}$

54 Khanin (1991), 41- 51.

55 Khanin (1991), 51- 102.

${ }^{56}$ Crawford and Sobel (1982).

${ }^{57}$ Stalin's treatment of planners and statisticians in the 1930s is discussed by Belova and Gregory (2001). In 1949 Stalin lost confidence in his formerly much favoured chief of the state planning commission N.A. Voznesenskii when the latter was alleged to have engaged in covering up a plan failure. This was the start of a process that ended in the latter's trial and execution; for relevant documents see Khlevniuk et al. (2002), 274- 85. 


\section{Soviet Growth, Transition, and Information}

At the twentieth party congress in 1956 Mikoian claimed that the Soviet state possessed statistical data "in far larger measure than at any other time and in any other country". Can he have told the truth?

In a superficial sense, possibly, yes. Our growing acquaintance with the archives is showing us that the statistical resources of the Soviet state were very, very large. However, the scale of these resources should be discounted by two factors: first, the sheer size of the Soviet economy and, second, the fact that the Soviet state combined government with functions undertaken in market economies by the private sector. When this is done the balance of advantage becomes less clear. Moreover, most Soviet information that was collected was restricted to a narrow sphere of circulation, and most of it was unreliable. Many kinds of information were not collected at all or, if collected, were not disseminated. For most of the time most officials had little idea about the true value of the physical and human resources at their disposal, the true productivity of the producers that they commanded or the true degree of satisfaction of the firms and households that they supplied. In short, the Soviet command system forced economic growth on the basis of an information stock of relatively low quality and low value.

Soviet and Russian postwar economic growth displays four features that demand explanation: rapid growth from the 1920s through the 1950s; the slowdown that began in the 1960s and set in more strongly in the 1970s; the collapse at the end of the 1980s, and the persistence of a low level of real output in the 1990s and since then. The Soviet economy's restricted information capacity can contribute to explaining all four. At the same time, given the present state of our knowledge, its explanatory power looks low. This is because all four problems already have too many possible solutions. ${ }^{58}$ It does not seem particularly useful to propose an extra solution to each problem when the data available do not allow us to discriminate among the solutions that have been advanced already. However, it may help to outline some possible avenues for further investigation.

Given low- value information stocks, how did the Soviet economy grow rapidly up to and through the 1950s? Soviet economic growth was based on the rapid expansion of output of standardised goods and services (but mostly goods) with low information requirements. Let me emphasise: it is not part of my argument that this growth was an illusion. The Soviet economy did grow. It grew in real terms and by several times over several decades. On the best measures available, between the 1920s and the 1980s Soviet real incomes per head increased by a factor of approximately five times. ${ }^{59}$ Real consumption

58 For a survey and investigation of competing explanations of Soviet economic growth and postwar slowdown see Harrison (1998b); for various explanations of Soviet economic collapse and a proposed solution see Harrison (2002).

59 Maddison (1995). 
grew by less, however, and the extra welfare gained from the growing supply of consumer goods and services was clearly lessened by shortages and other restrictions on variety and choice, and by social and intertemporal inequalities. Moreover, although the level of the information stock may have been low relative to real output, it was presumably possible to widen this stock as output grew so that information shortages did not constrain growth. The outcome was that by the 1980s the Soviet Union had achieved an income level many times higher than could have been predicted from its endowment with information handling equipment measured by computing power. ${ }^{60}$

New research on long- run trends in the organisation of market economies suggests that the conditions under which the Soviet economy could grow like this were temporary. The century from 1870 to 1970 was characterised by two special conditions in which large hierarchical organisations could flourish: industry was providing a rising scale of production, while the modern office had reduced costs of information and monitoring to a level that was, as yet, "neither prohibitive nor trivial". Since then, however, further declines in information costs have favoured a switch away from hierarchies back to horizontally organised networks based on trust, reputation, and customised production. ${ }^{61}$ In short, the Soviet model of rapid industrialisation that relied on standardisation and sparse information was favoured by special conditions of the last century that no longer exist.

The character of Soviet information stocks may help explain Soviet postwar productivity slowdown. The evidence of the Soviet real growth series is that there was a sharp deceleration in the mid-1970s that cannot be explained by any exogenous shock. 62 This was just the time when in other countries information costs began to fall much more rapidly and at the same time demand shifted more decisively towards more information-intensive products and services. Globally perhaps the return to information was increasing relative to other resources such as labour and other kinds of capital where returns were falling. Suppose that Soviet information channels could not be deepened to supply the information that would have maintained the returns to other factors in the Soviet economy. Then, a slowdown of aggregate and productivity growth was the inevitable result.

60 See Iacopetta (2001) for this finding and a new investigation and analysis of the Soviet postwar failure to adopt new information technologies. Probably the gap that Iacopetta found between incomes and computing power was eliminated in the 1990s by the collapse of Russian incomes. The classic general investigation of the poor Soviet innovation record is Berliner (1976).

61 Broadberry and Ghosal (2001a, 2001b), and Lamoreaux, Raff, and Temin (2000) from which the quoted words are taken. I thank Stephen Broadberry for many discussions on these issues.

62 Harrison (1998b). 
Consider more specifically how information relates to knowledge. Knowledge in the sense of "how to" and "can do" is useless without information. Decade after decade the Soviet education system increased the numbers of knowledgeable people whose desire for information was perhaps increasingly frustrated. ${ }^{63}$ As a result the returns to investments in human capital fell or proved unexpectedly low.

The low value of Soviet information stocks may also add to our understanding of how the Soviet command system eventually collapsed. According to Mancur Olson a dictator of the stationarybandit type will invest in public goods such as protection of the physical and human assets under his control up to the point where his share in their return to society equals the cost to him of doing so. ${ }^{64}$ Public information is a public good but if information is costly and the return on publication accrues mainly to society the dictator will keep it to himself or not provide it. The dictator administers his assets through agents. Each agent will stay loyal to the dictator provided his share in the dictator's expected rents from the assets he administers exceeds the expected value of the asset if he stole it. Among these assets must be counted the dictator's secrets. These secrets had a value to the dictator if kept, and a value in the economic or political market place if disclosed. One aspect of the process that began with glasnost' and ended in the dismantling of the Soviet state was the moment when agents began to realise that the market value of state secrets long preserved under their control exceeded their value if left in concealment. At this point stealing information became one more dimension of what Steven Solnick has called "stealing the state". 65

Finally, the inheritance of a low-value information stock may help to explain the persistence of a low level of output after the transition to a market system. The important role of intangible "social capital" in long run economic development has long been accepted by economic historians. ${ }^{66}$ More recently the poor economic performance of the former Soviet republics since the collapse of the command system has been attributed to low social capital in the form of an institutional quality deficit. 67 Earlier optimism about the growth prospects of transitional economies is necessarily tempered when this deficit is fully

63 The idea that the spread of education would eventually force a more open society in the USSR is not new; see for example Deutscher (1967), 59- 60: "The force of the revolutionary tradition has been great enough to compel the bureaucracy to give the workers much more education than has been required on narrow economic grounds, and perhaps more than is safe for the privileged groups. It may be argued that the bureaucracy is thus breeding its own grave- diggers".
64 Olson (1993).
65 Solnick (1998).
66 Abramowitz (1986).
67 World Bank (1996). 
taken into account. 68 The command system impeded the accumulation of social capital but could force economic growth by relying on coercion instead. Now that the command system has gone, a market economy will not prosper in Russia until the necessary accumulation of social capital has taken place, a process that could take decades or centuries.

Social capital is conventionally measured along several dimensions: education and knowledge, the rule of law and property rights, a civil society, and so on. What makes these things "social" rather than private in nature is that their benefits spill over the narrow limits of private profit and loss. In this sense information stocks are also a part of social capital. The Russian economy today is suffering from a shortage of the information stocks that make transactions valuable and make markets work. Accumulating the missing information stocks will take time, and will not even begin without progress in the complementary dimensions of social capital that are already recognised in the literature.

\section{Conclusions}

The economics of information analyses some of the ways in which information adds value to transactions in market economies. While markets may thrive on information, hierarchies may choke on it. In the Soviet command economy valuable information was frequently not produced; if produced, it was often concealed; whether concealed or not, it was often of poor quality; regardless of quality, it often suffered from low credibility outside the ruling circle. In short, the Soviet command system forced economic growth on the basis of a relatively low-value information stock. This may help explain aspects of Soviet postwar economic growth and slowdown, the collapse of the command system, and the persistence of low output since the collapse. At the moment, however, such suggestions are no more than speculations because we have virtually no empirical measures of trends in the quantity or value of the command system's information stocks, flows, or transfers.

68 Crafts and Kaiser (2002). 


\section{References}

Abramovitz, Moses (1986), "Catching Up, Forging Ahead, and Falling Behind", J ournal of Economic History, 46(2), 385- 406

Arrow, Kenneth J . (1984), Collected Papers of Kenneth J . Arrow, vol. 4, The Economics of Information, Oxford: Blackwell

Barber, J ohn, Mark Harrison, Nikolai Simonov, and Boris Starkov (2000), "The Structure and Development of the Soviet DefenceIndustry Complex", in J ohn Barber and Mark Harrison, eds, The Soviet Defence- Industry Complex from Stalin to Khrushchev, London and Basingstoke: Macmillan, 3- 32

Bell, H.E. (1936), "The Price of Books in Medieval England", The Library, 4th series, 17(3), 312- 32

Belova, Eugenia (2001), "Contract Enforcement Under Dictatorship: the Case of the Soviet Economy", PERSA Working Paper no. 14, University of Warwick, Department of Economics

Belova, Eugenia, and Paul R. Gregory (2001), "Dictators, Loyal and Opportunistic Agents, and Punishment: the Soviet Archives on Creating the Soviet Economic System", PERSA Working Paper No. 2, University of Warwick, Department of Economics, forthcoming in Public Choice

Berliner, J oseph S. (1976), The Innovation Decision in Soviet Industry, Cambridge, MA: MIT Press

Broadberry, S.N. (1997), The Productivity Race: British Manufacturing in International Perspective, 1850- 1990, Cambridge: Cambridge University Press

Broadberry, S.N., and Sayantan Ghosal (2001a), “Networks, Hierarchies, and Economic Performance", University of Warwick, Department of Economics

Broadberry, S.N., and Sayantan Ghosal (2001b), "Technology, Organisation, and Productivity Performance in Services: Lessons from Britain and the United States, 1870-1990”, University of Warwick, Department of Economics

Cipolla, Carlo M. (1956), Money, Prices, and Civilization in the Mediterranean World: Fifth to Seventeenth Century, Princeton NJ : Princeton University Press

Crafts, Nicholas, and Kai Kaiser (2002), "Long-Term Growth Prospects in Transition Economies: A Reappraisal”, London School of Economics

Crawford, Vincent P., and J oel Sobel (1982), "Strategic Information Transmission", in Econometrica, 50(6), 1431- 51

David, Paul A., and Dominique Foray (2001), "An Introduction to the Economy of the Knowledge Society", All Souls College, Oxford

Deutscher, Isaac, The Unfinished Revolution: Russia, 1917- 1967, Oxford: Oxford University Press

Ehrlich, Éva (1968), "Nemzetközi elemzések a magyar távlati tervezéshez”, Országos Tervhivatal Tervgazdasági Intézet, no. 2, 1- 175

Goodhart, C.A.E. (1984), Monetary Theory and Practice: the UK Experience, London: Macmillan 
Gregory, Paul R. (1990), Restructuring the Soviet Economic Bureaucracy, Cambridge: Cambridge University Press

Gordon, Robert J . (1990), The Measurement of Durable Goods Prices, Chicago: University of Chicago Press

Harrison, Mark (1994), "GDPs of the USSR and Eastern Europe: Towards an Interwar Comparison”, Europe- Asia Studies, 46, 24359

Harrison, Mark (1998a), “Prices, Planners, and Producers: an Agency Problem in Soviet Industry, 1928- 1950", J ournal of Economic History, 58 (4), 1032- 62.

Harrison, Mark (1998b), "Trends in Soviet Labour Productivity, 19281985: War, Postwar Recovery, and Slowdown”, European Review of Economic History, 2(2), 171- 200

Harrison, Mark (2000a), "Soviet Industrial Production, 1928 to 1955: Real Growth and Hidden Inflation", J ournal of Comparative Economics, 28(1), 134- 55

Harrison, Mark (2000b), "Wartime Mobilisation: A German Comparison", in Mark Harrison and J ohn Barber, eds. The Soviet Defence Industry Complex from Stalin to Khrushchev, London and Basingstoke: Macmillan, 99- 117

Harrison, Mark (2001a), "Providing for Defense”, in Paul R. Gregory, ed., Behind the Façade of Stalin's Command Economy, Stanford, CA: Hoover Institution Press, 81-110

Harrison, Mark (2001b), "The Soviet Market for Inventions: The Case of J et Propulsion, 1932 to 1944" PERSA Working Paper no. 9, University of Warwick, Department of Economics

Harrison, Mark (2001c), "The Political Economy of a Soviet Military R\&D Failure: Steam Power for Aviation, 1932 to 1939”, PERSA Working Paper no. 12, University of Warwick, Department of Economics, forthcoming in the J ournal of Economic History

Harrison, Mark (2001d), "Soviet Industry and the Red Army Under Stalin: A Military- Industrial Complex?", The Warwick Economic Research Papers no. 609, University of Warwick, Department of Economics, forthcoming in Cahiers du monde Russe

Harrison, Mark (2002), "Coercion, Compliance, and the Collapse of the Soviet Command Economy”, Economic History Review, 55(3), forthcoming

Harrison, Mark, and Nikolai Simonov (2000), "Voenpriemka: Prices, Costs, and Quality in Defence Industry", in Mark Harrison and J ohn Barber, eds. The Soviet Defence Industry Complex from Stalin to Khrushchev, London and Basingstoke: Macmillan, 223- 45

Hayek, F.A. (1945), "The Use of Knowledge in Society," American Economic Review, 35(4) 519- 30

Holloway, David (1994), Stalin and the Bomb: the Soviet Union and Atomic Energy, 1939- 1956, New Haven, CT: Yale University Press

Holzman, Franklyn D. (1974), Foreign Trade Under Central Planning, Cambridge, MA: Harvard University Press

Iacopetta, Maurizio (2001), "Dissemination of Technology in Market and Planned Economies", New York University, Department of Economics, 
International Monetary Fund (1997), World Economic Outlook, Washington DC: IMF

Katz, Michael L., and Carl Shapiro (1985), "Network Externalities, Competition, and Compatibility", American Economic Review, 75 (3), 424- 40.

Khanin, G.I. (1991), Dinamika ekonomicheskogo razvitiia SSSR, Novosibirsk: Nauka

Khlevniuk, O.V., A.V. Kvashonkin, L.P. Kosheleva, and L.A. Rogovaia, eds (1995), Stalinskoe Politbiuro v 30-e gody. Sbornik dokumentov, Moscow: AIRO-XX

Khlevniuk, O.V., I. [Yoram] Gorlitskii [Gorlizki], L.P. Kosheleva, A.I. Miniuk, M.Iu. Prozumenshchikov, L.A. Rogovaia, and S.V. Somonova, eds (2002), Politbiuro TsK VPK(b) i Sovet Ministrov SSSR. 1945- 1953, Moscow: ROSSPen

Kudrov, V.M. (1997), Sovetskaia ekonomika v retrospektive. Opyt pereosmysleniia, Moscow: Nauka

Lamoreaux, Naomi, Daniel M.G. Raff, and Peter Temin (2000), "Beyond Markets and Hierarchies: Towards a New Synthesis of American Business History", UCLA- University of PennsylvaniaMIT

Landefield, J . Steven, and Bruce T. Grimm (2000), "A Note on the Impact of Hedonics and Computers on Real GDP", Bureau of Economic Analysis Survey of Current Business, December, 17- 22

Lazarev, Valery, and Paul R. Gregory (2001), "Dictators and Cars: a Case Study in the Political Economy of Dictatorship", PERSA Working Paper No. 5, University of Warwick, Department of Economics

Ledeneva, Alena V. (1998), Russia's Economy of Favours: Blat, Networking and Informal Exchange, Cambridge: Cambridge University Press

Maddison, Angus (1995), Monitoring the World Economy, 1820-1992, Paris: OECD

Madrick, Jeff (2001), "The Business Media and the New Economy”, Harvard University, J ohn F. Kennedy School of Government, J oan Shorenstein Centre Research Paper R- 24

Nove, Alec (1958), 'The Problem of 'Success Indicators' in Soviet Industry", Economica, 25(97), 1- 13

Olson, M. (1993), "Dictatorship, Democracy, and Development", American Political Science Review, 87(3), 567- 76

Shapiro, Carl (1983), "Premiums for High Quality Products as Returns to Reputations", Quarterly J ournal of Economics, 98(4), 659- 80

Shleifer, Andrei (1985), "A Theory of Yardstick Competition”, RAND J ournal of Economics, 16(3), 319-27

Solnick, Steven L. (1998), Stealing the State: Control and Collapse in Soviet Institutions, Cambridge, MA: Harvard University Press

Stalin, J oseph (1940), Leninism, London: Lawrence \& Wishart

Stigler, George J . (1961), "The Economics of Information”, J ournal of Political Economy, 69(3), 213- 225

Treml, Vladimir G., and J ohn P. Hardt, eds (1972), Soviet Economic Statistics, Durham, NC: Duke University Press 
Wheatcroft, S.G., and R.W. Davies (1994), "The Crooked Mirror of Soviet Economics Statistics”, in R.W. Davies, Mark Harrison, and S.G. Wheatcroft, eds, The Economic Transformation of the Soviet Union, 1913- 1945, Cambridge: Cambridge University Press, 24- 37

Wintrobe, Ronald (1990), "The Tinpot and the Totalitarian: an Economic Theory of Dictatorship", American Political Science Review, 84(3), 849- 72

Wintrobe, Ronald (1998), The Political Economy of Dictatorship, Cambridge: Cambridge University Press

World Bank (1996), From Plan to Market: World Development Report, 1996, Washington DC: The World Bank

World Bank (2001), World Development Indicators, Washington, DC: The World Bank

Zaleski, Eugene (1971), Planning for Economic Growth in the Soviet Union, 1918- 1932, Chapel Hill, NC: University of North Carolina Press 